\title{
Effects of Different Pond Aquaculture Systems on Water Environments, and Suggestions for Structural Adjustments
}

\author{
Yajun Chang", Wei Wang", Xiaojing Liu, Fengfeng Du, Dongrui Yao* \\ Institute of Botany, Jiangsu Province and Chinese Academy of Sciences, Nanjing Botanical Garden, \\ Mem. Sun Yat-Sen, Nanjing, P.R. China
}

Received: 5 July 2018

Accepted: 27 December 2018

\begin{abstract}
The water quality of six different aquaculture systems in freshwater ponds was investigated in Jiangsu Province of China in order to elucidate the influence of different aquaculture systems on water quality. The six aquaculture systems involved in this study were: monoculture of shrimps and crabs, polyculture of shrimps and crabs, polyculture of fish and crabs, polyculture of crabs and various types of fish, and polyculture of different types of fish. The results showed that the water temperature of those six aquaculture ponds decreased from south to north and that all DO values were higher than standard value of Grade I water for Surface Water Quality Standards in China (GB 3838-2002) (DO $\geq 7.5 \mathrm{mg} / \mathrm{L}$ ). For all systems, the $\mathrm{pH}$ values ranged between 7.36 and 8.54 , and nitrite concentrations were below China's aquaculture water standard value $(0.12 \mathrm{mg} / \mathrm{L})$; however, all ammonia concentrations were higher than the national standard $(0.20 \mathrm{mg} / \mathrm{L})$. In comparison, water quality from the monoculture of shrimp and crabs was much better than that from other aquaculture combinations. Polyculture of different types of fish showed the highest nitrite $(0.030 \mathrm{mg} / \mathrm{L})$ and ammonia $(0.86 \mathrm{mg} / \mathrm{L})$ concentrations among the six aquaculture systems. In general, the pond aquaculture in china is in a rough management state, and strict and reasonable control of the aquaculture is urgently needed. So it is highly recommended that we establish an ecological and healthy aquaculture mode suitable for sustainable development of the aquaculture industry in China.
\end{abstract}

Keywords: freshwater aquaculture, ponds, aquaculture systems, nitrogen, phosphorus

\section{Introduction}

Since the reform and opening up, the rapid development of China's aquaculture industry has achieved remarkable accomplishments. The aquaculture

\#Authors who contributed equally to this paper

*e-mail: shuishengzu@126.com production increased from $3.626 \times 10^{6} \mathrm{t}$ in 1985 to $5.018 \times 10^{7} \mathrm{t}$ in 2015 . In the past 30 years, the proportion of aquaculture in Chinese fisheries has nearly quadrupled, increasing from $45 \%$ to $75 \%$, and becoming the world's largest aquaculture producer (accounting for about $2 / 3$ of the global aquaculture production) [1]. Aquaculture, as one of the fastest growing industries of China's agriculture, has made important contributions 
for ensuring market supply, increasing farmers' incomes, and improving the export competitiveness of agricultural products. However, the rapid development of the aquaculture industry has caused serious environmental pollution, which has been becoming a major concern for water resources in China, and it has become the third largest source of pollution following industrial and domestic pollution. Pond aquaculture is the main system for freshwater aquaculture in China and it accounted for $71.5 \%$ of China's freshwater aquaculture in 2014 [2]. The aquaculture water in ponds is not only the source of aquatic breeding and cultivation, but also the decomposition site of feces, bait, etc. The decomposition of these substances not only increases the load of organic matter in water, but also accumulates in the sediment of the pond, aggravating the endogenous pollution of the water. Now, the concept of "ecology, health, and sustainable aquaculture"has been advocated by the Chinese government [3-4]. The technology of "integrated rice-fish breeding" has been widely used in China, Bangladesh, Vietnam, and Japan [5-8]. However, different systems or combinations of pond aquaculture resulting from a variety of cultured species, density, and breeding, have divergent effects on the water environment.

Jiangsu Province, with a total area of $1.072 \times 10^{6} \mathrm{~km}^{2}$, is located in eastern China (116 $18^{\circ}$ $\left.121^{\circ} 57^{\prime} \mathrm{E}, 30^{\circ} 45^{\prime}-35^{\circ} 20^{\prime} \mathrm{N}\right)$. The water coverage area of $1.73 \times 10^{5} \mathrm{~km}^{2}$ makes Jiangsu the largest province regarding water coverage among all provinces in China [9]. The aquaculture areas in Jiangsu reached $0.80 \times 10^{5} \mathrm{~km}^{2}$ in 2016 , and at present the aquaculture industry plays a key role in the development of Jiangsu agricultural economy [10]. Jiangsu, based on the Yangtze and Huaihe rivers, can be divided into three regions - South, Central, and North - and the aquaculture species used in these three regions are quite different, showing apparent regional characteristics. For example, in the area of Yangcheng Lake of southern Jiangsu, the aquaculture species of ponds are dominated by hairy crabs, while in the Luoma Lake area of northern Jiangsu, pond aquaculture is dominated by fish. Differences in aquaculture structures lead to differences in aquaculture water in ponds, which further results in different pollution effects of water surroundings and ecological environmental benefits. On the other hand, the quality of aquaculture water in ponds will in turn affect the yield and quality of the aquaculture products, thus affecting the economic benefits of the aquaculture.

Therefore, as a representative aquaculture province, Jiangsu was selected and used as one of the main research areas in China. Six different aquaculture systems in ponds were investigated and compared in order to clarify their influence on the resulting water quality. Based on these research findings, suggestions for the adjustment of local aquaculture structure and the development of environmentally friendly aquaculture mode are introduced.

\section{Material and Methods}

\section{Study Site}

Six sites were selected for the present study in Jiangsu Province (Fig. 1), which are located in the areas of Suzhou Yangcheng Lake, Suzhou Taicang Dulou Xiaohai, Taizhou Qiuxue Lake, Yangzhou Gaoyou Lake, Huai'an Hongze Lake, and Suqian Luoma Lake. The research coverage spanned almost the whole area of Jiangsu from south to north.

\section{Structure of Pond Aquaculture}

The six study sites represented respectively six different aquaculture structures in ponds (see Fig. 1). The aquaculture regions located in Suzhou Yangcheng, Suzhou Taicang Dulou Xiaohai, Taizhou Qiuxue, Yangzhou Gaoyou, Huai'an Hongze, and Suqian Luoma

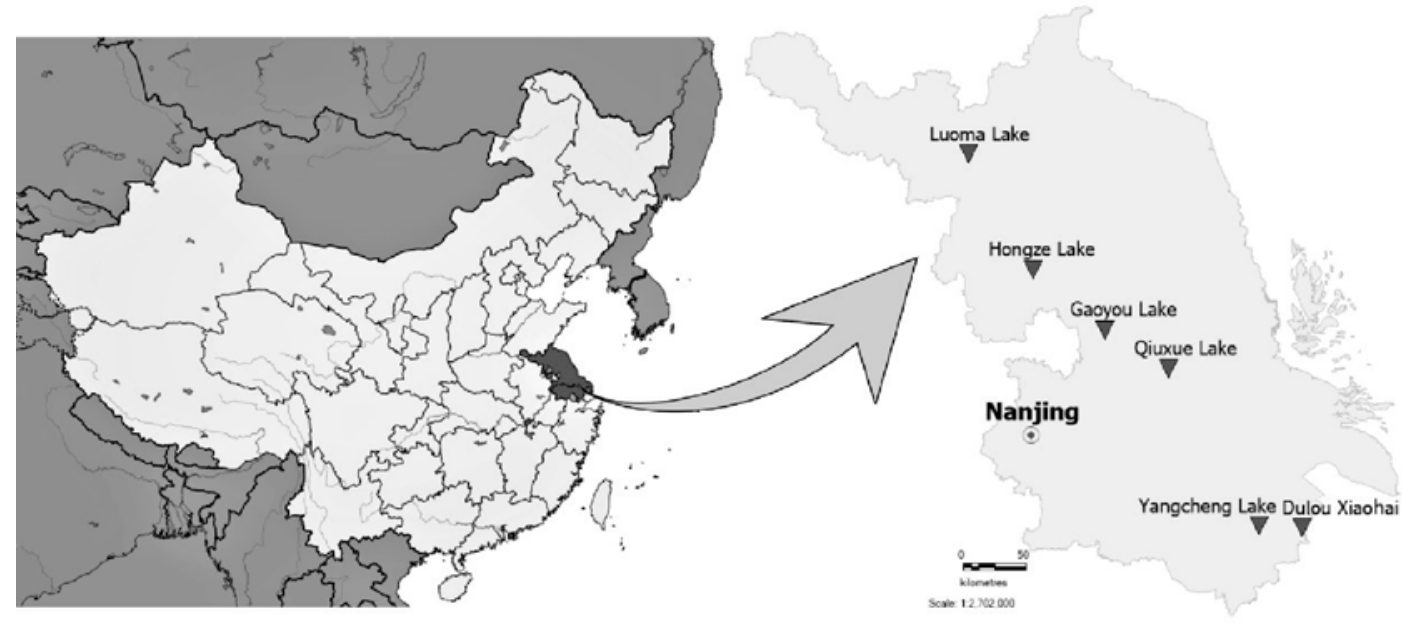

Fig. 1. Six study sites in Jiangsu Province. 
Table 1. Breeding density and area size of the six different aquaculture ponds.

\begin{tabular}{|c|c|c|c|}
\hline Sample site & Breeding structure & Breeding density (per hectare) & $\begin{array}{c}\text { Size of sample } \\
\text { site (hectare) }\end{array}$ \\
\hline $\begin{array}{c}\text { Qiuxue Lake } \\
\text { in Taizhou }\end{array}$ & Monoculture of Macrobrachium rosenbergii & 600000 & 4.0 \\
\hline $\begin{array}{c}\text { Yangcheng Lake } \\
\text { in Suzhou }\end{array}$ & Monoculture of Eriocheir sinensis (Chinese mitten crab) & 13500 & 1.2 \\
\hline $\begin{array}{c}\text { Gaoyou Lake } \\
\text { in Yangzhou }\end{array}$ & Polyculture of Eriocheir sinensis and Macrobrachium \\
\hline $\begin{array}{c}\text { ruosenbergii } \\
\text { in Suqian }\end{array}$ & Polyculture of Eriocheir sinensis and Aristichthys nobilis & $\begin{array}{c}2250,3000 \text {; extensive low density } \\
\text { breeding without feeding }\end{array}$ & 2.0 \\
\hline $\begin{array}{c}\text { Hongze Lake } \\
\text { in Huaian }\end{array}$ & $\begin{array}{c}\text { Polyculture of Eriocheir sinensis, Ctenopharyngodon } \\
\text { idellus, Carassius auratus and Leiocassis longirostris }\end{array}$ & $\begin{array}{c}4500,750-1500,750-1500, \\
750-1500\end{array}$ & 1.4 \\
\hline $\begin{array}{c}\text { Dulou Xiaohai } \\
\text { in Taicang }\end{array}$ & $\begin{array}{c}\text { Polyculture of Mylopharyngodon piceus, Ctenopharyngo- } \\
\text { don idellus, Parabramis pekinensis, Aristichthys nobilis, } \\
\text { Hypophthalmichthys molitrix and Carassius auratus }\end{array}$ & $\begin{array}{c}45,4290,1155,795,1515,5700 \\
1.6\end{array}$ & 1.6 \\
\hline
\end{tabular}

lakes were accustomed to using crab monoculture, polyculture of different types of fish, monoculture of shrimp, polyculture of shrimp and crab, polyculture of crabs and various types of fish, and polyculture of fish and crabs, respectively. Breeding combinations, breeding density, and aquaculture scale for each aquaculture structure are detailed in Table 1.

\section{Sampling and Measurements}

At the end of November 2017, six indicators of water quality, temperature (Tm), $\mathrm{pH}$, dissolved oxygen (DO), oxidation-reduction potential(ORP), salinity (SAL), and electrical conductivity (EC) were measured in each of six ponds), in situ by YSI Professional Plus at a depth of $50 \mathrm{~cm}$ below the water surface. Water samples were collected via water sampler (CS-100 type plexiglass, $2.5 \mathrm{~L}$ ) from the ponds at depth of $50 \mathrm{~cm}$ from the water surface. Six samples from a pond were taken and mixed in a clean plastic bottle as a biological replicate, with three replicates for each pond. All water samples were taken back to the laboratory within 4 hours. Then all samples were immediately frozen at $-20^{\circ} \mathrm{C}$ for later analysis. For water samples, TN and TP were analyzed according to standard methods [11]. $\mathrm{NH}_{3}$ was measured by Nessler's reagent spectrophotometry according to standard methods (HJ 535-2009) [12]. Nitrate and nitrite nitrogen were determined via UV spectrophotometry according to the standard methods (HJ/T 346-2007) [13]. Furthermore, chlorophyll a was determined using ethanol and spectrophotometry after suction filtration.

\section{Statistical Analysis}

All statistical analyses were performed using statistical package for the social sciences 22.0 (SPSS 22.0) package and expressed as mean \pm SD. Data were analyzed by one-way analysis of variance (ANOVA), and significance was set at $\mathrm{P}<0.05$. Multiple comparisons among means were conducted with Duncan's new multiple range test.

\section{Results and Discussion}

\section{Basic Water Quality for Ponds with Different Aquaculture Systems}

Assessment of water quality for aquaculture ponds with different systems is shown in Table 2. The water temperature of six different aquaculture ponds changed between 7.12 and $3.46^{\circ} \mathrm{C}$ from south to north, according to the geographical locations in Jiangsu (Fig. 1). the value of dissolved oxygen (DO) in six aquaculture ponds ranged from 11.36 to $17.09 \mathrm{mg} / \mathrm{L}$, which was higher than the standard value of the Grade I water for the Surface Water Quality Standards in China (DO>7.5 mg /L) [14]. This value was also far higher than that of the Chinese fishery standard, indicating that DO in water of all aquaculture ponds was surplus. The $\mathrm{pH}$ of all the pond water was between 7.36 and 8.54, indicating that the water of all aquaculture ponds was weakly alkaline under the different aquaculture systems. A wide variation of chlorophyll a was found among different aquaculture water bodies. The chlorophylla concentration of $147.45 \mathrm{ug} / \mathrm{L}$ was detected in the pond systems with different types of fishpolycultures, while chlorophyll a content below $4.00 \mathrm{ug} / \mathrm{L}$ was observed for all other aquaculture water bodies. The higher chlorophyll a in the ponds with different fish polycultures might be explained by the fact that the polyculture mode needs more feed, while the feed supply is bound to cause an increase of fish feces, feed residues, and other organic matter. Meanwhile, the decomposition of these organic matters would increase nitrogen and phosphorus contents in aquaculture water, which could cause an outbreak of cyanobacteria and other microbes in corresponding water bodies [15]. 
Table 2. Water quality parameters of the six different aquaculture systems in winter.

\begin{tabular}{|c|c|c|c|c|c|c|c|}
\hline & \multicolumn{4}{|c|}{ Physical parameters } & \multicolumn{2}{|c|}{ Chemical parameters } & \multirow{2}{*}{$\begin{array}{c}\text { Biological } \\
\text { parameters }\end{array}$} \\
\hline & $\begin{array}{c}\text { Temperature } \\
\left({ }^{\circ} \mathrm{C}\right)\end{array}$ & Salinity (ppt) & $\begin{array}{l}\text { Conductivity } \\
\text { (us/cm) }\end{array}$ & OPR (mV) & $\mathrm{pH}$ & $\mathrm{DO}(\mathrm{mg} / \mathrm{L})$ & \\
\hline $\begin{array}{l}\text { Qiuxue Lake } \\
\text { in Taizhou }\end{array}$ & $6.02 \pm 0.28 \mathrm{c}$ & $0.212 \pm 0.008 \mathrm{~d}$ & $276.92 \pm 1.36 \mathrm{c}$ & $143.72 \pm 0.27 \mathrm{~d}$ & $8.41 \pm 0.20 \mathrm{~b}$ & $14.79 \pm 0.24 \mathrm{~b}$ & $1.008 \pm 0.014 b$ \\
\hline $\begin{array}{l}\text { Yangcheng Lake } \\
\text { in Suzhou }\end{array}$ & $6.46 \pm 0.21 \mathrm{~b}$ & $0.192 \pm 0.011 \mathrm{e}$ & $250.28 \pm 1.21 \mathrm{e}$ & $133.20 \pm 0.10 \mathrm{e}$ & $10.30 \pm 0.16 \mathrm{a}$ & $17.09 \pm 0.14 \mathrm{a}$ & $1.642 \pm 0.035 b$ \\
\hline $\begin{array}{l}\text { Gaoyou Lake } \\
\text { in Yangzhou }\end{array}$ & $4.14 \pm 0.25 \mathrm{~d}$ & $0.196 \pm 0.009 \mathrm{e}$ & $255.06 \pm 0.91 d$ & $93.10 \pm 0.23 \mathrm{f}$ & $8.44 \pm 0.22 b$ & $13.11 \pm 0.25 \mathrm{~d}$ & $1.895 \pm 0.058 \mathrm{~b}$ \\
\hline $\begin{array}{l}\text { Luoma Lake } \\
\text { in Suqian }\end{array}$ & $3.46 \pm 0.21 \mathrm{e}$ & $0.316 \pm 0.009 \mathrm{a}$ & $398.68 \pm 1.08 \mathrm{a}$ & $273.00 \pm 0.12 \mathrm{a}$ & $7.41 \pm 0.12 \mathrm{c}$ & $11.68 \pm 0.17 \mathrm{e}$ & $2.955 \pm 0.114 \mathrm{~b}$ \\
\hline $\begin{array}{l}\text { Hongze Lake } \\
\text { in Huai'an }\end{array}$ & $4.16 \pm 0.18 \mathrm{~d}$ & $0.236 \pm 0.009 \mathrm{c}$ & $296.20 \pm 1.47 b$ & $254.30 \pm 0.12 b$ & $7.36 \pm 0.17 \mathrm{c}$ & $11.36 \pm 0.31 \mathrm{f}$ & $3.152 \pm 0.081 b$ \\
\hline $\begin{array}{l}\text { Dulou Xiaohai } \\
\text { in Taicang }\end{array}$ & $7.12 \pm 0.22 \mathrm{a}$ & $0.296 \pm 0.009 \mathrm{~b}$ & $399.90 \pm 1.24 \mathrm{a}$ & $159.12 \pm 0.22 \mathrm{c}$ & $8.54 \pm 0.21 \mathrm{~b}$ & $13.42 \pm 0.18 \mathrm{c}$ & $147.454 \pm 1.564 \mathrm{a}$ \\
\hline
\end{tabular}

Nitrogen Concentrations in the Ponds with Different Aquaculture Systems

The nitrogen levels for different aquaculture water bodies in six ponds are shown in Figs 2 and 3. The lowest nitrogen level was detected in the water body of the ponds with monoculture of crab, with the concentrations of $\mathrm{TN}$ of $0.90 \mathrm{mg} / \mathrm{L}, \mathrm{NO}_{3}{ }_{3} \mathrm{~N}$ $0.06 \mathrm{mg} / \mathrm{L}, \mathrm{NO}_{2}{ }^{-} \mathrm{N} 0.007 \mathrm{mg} / \mathrm{L}$ and $\mathrm{NH}_{3} 0.16 \mathrm{mg} / \mathrm{L}$. The nitrogen concentration in water body of the monoculture of shrimp was the second lowest, followed by that of the monoculture of crab. However, the nitrogen level, TN $1.81 \mathrm{mg} / \mathrm{L}, \mathrm{NO}_{3}{ }^{-} \mathrm{N} 1.22 \mathrm{mg} / \mathrm{L}$,
$\mathrm{NO}_{2}{ }^{-} \mathrm{N} \quad 0.016 \mathrm{mg} / \mathrm{L}$ and $\mathrm{NH}_{3} \quad 0.71 \mathrm{mg} / \mathrm{L}$, in the aquaculture water of polyculture of both crab and shrimp were significantly higher than those in the pond of monoculture of crab or shrimp, which indicates that the water quality varies greatly between polyculture and monoculture modes. In addition, the concentrations of $\mathrm{TN} 1.47 \mathrm{mg} / \mathrm{L}$ and $\mathrm{NH}_{3}$ $0.41 \mathrm{mg} / \mathrm{L}$ in the water bodies from the polyculture pond of the crab-fish were much lower than that (TN $1.99 \mathrm{mg} / \mathrm{L}$ and $\mathrm{NH}_{3} 0.70 \mathrm{mg} / \mathrm{L}$ ) from the polyculture pond of crab and mult-species fish. Moreover, a polyculture pond with different types of fish displayed the highest $\mathrm{TN}$ and $\mathrm{NO}_{2}^{-} \mathrm{N}$ levels of $2.19 \mathrm{mg} / \mathrm{L}$ and
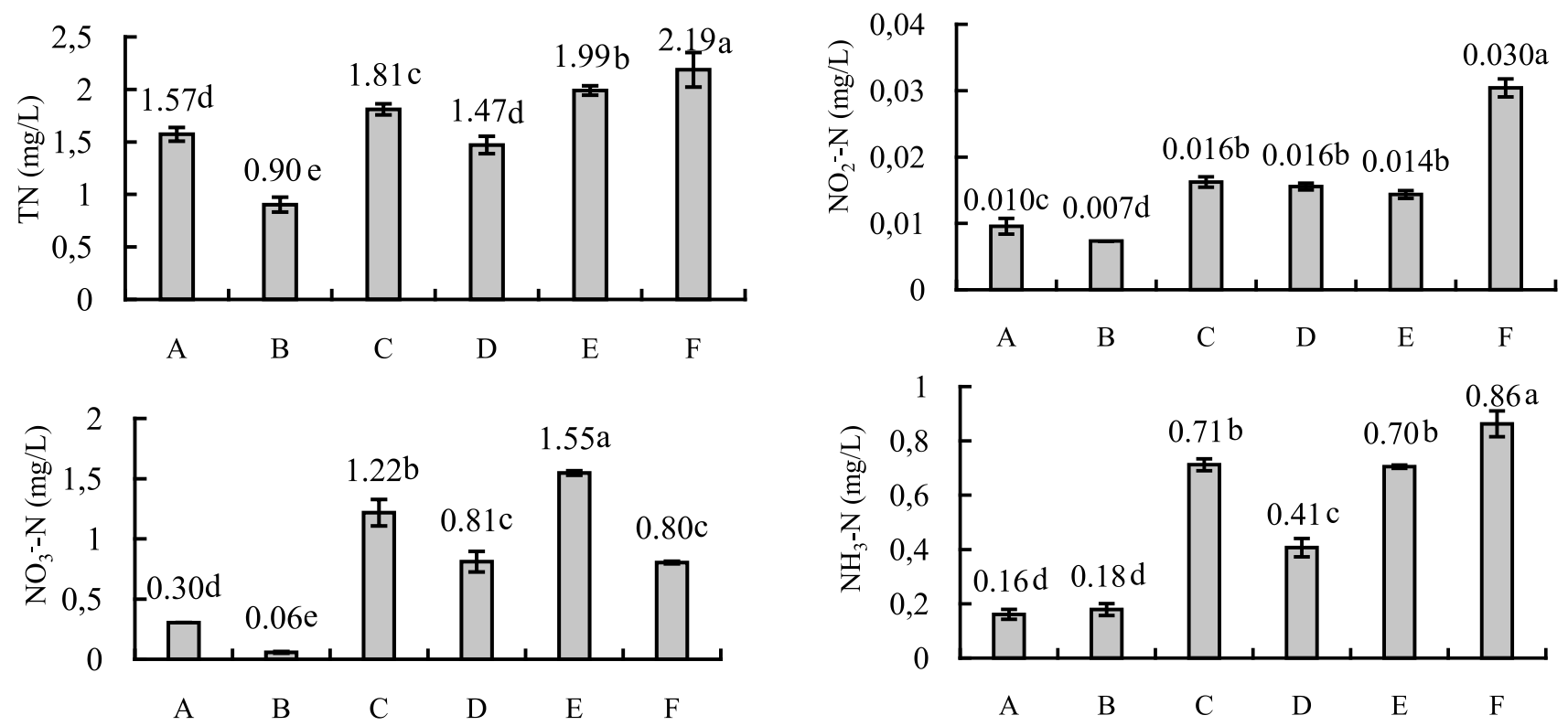

Fig. 2. Concentrations of total nitrogen and nitrate in water bodies of the six different aquaculture systemsin winter: A) Qiuxue Lake, B) Yangcheng Lake, C) Gaoyou Lake, D) Luoma Lake, E) Hongze Lake, F) Dulou Xiaohai.

Fig. 3. Concentrations of nitrite nitrogen and ammonia nitrogen in water bodies of the six different aquaculture systems in winter: A) Qiuxue Lake, B) Yangcheng Lake, C) Gaoyou Lake, D) Luoma Lake, E) Hongze Lake, F) Dulou Xiaohai. 


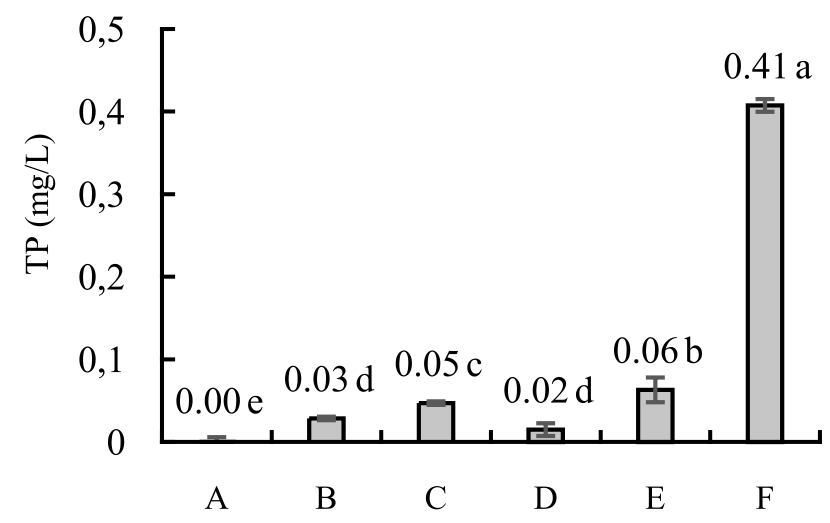

Fig. 4. Total phosphorus content in water bodies of the six different aquaculture systems in winter: A) Qiuxue Lake, B) Yangcheng Lake, C) Gaoyou Lake, D) Luoma Lake, E) Hongze Lake, F) Dulou Xiaohai.

$0.030 \mathrm{mg} / \mathrm{L}$, which exceed the Chinese fishery aquaculture water standard [16].

The accumulation of $\mathrm{NO}_{2}^{-} \mathrm{N}$ and $\mathrm{NH}_{3}$ in aquaculture water would cause the occurrence of fish poisoning [17, 18]. Therefore, the related agency in China has worked out a national standard for $\mathrm{NO}_{2}^{-} \mathrm{N}$ and $\mathrm{NH}_{3}$ levels in aquaculture water bodies. Although the concentrations of nitrite in the water of the six pond systems were much lower than the national standard $(0.12 \mathrm{mg} / \mathrm{L})$ of the fishery aquaculture water, the ammonia level was higher than the national standard of $0.20 \mathrm{mg} / \mathrm{L}$. Normally, the concentration of ammonia nitrogen should be strictly controlled below $0.20 \mathrm{mg} / \mathrm{L}$ in aquaculture water during the growing season, otherwise the fish would suffer from ammonia poisoning symptoms or even die due to a too-high ammonia nitrogen level [19]. However, in the present study the residues and feces in the breeding process would be continually deposited in the bottom of the ponds if post-harvest sampling was used [20]. These compounds in pond bottoms would be decomposed in the later stage, resulting in an excess of ammonia nitrogen in the aquaculture water bodies.

\section{TP Concentrations in Ponds with Different Aquaculture Systems}

The TP levels in water bodies of the six ponds with different aquaculture structures are shown in Fig. 4. The aquaculture water with shrimp monoculture showed the lowest TP value of $0.01 \mathrm{mg} / \mathrm{L}$ among the six aquaculture systems, while the highest TP concentration of $0.41 \mathrm{mg} / \mathrm{L}$ was detected in water bodies of the polyculture pond with different types of fishes. It is noteworthy that the TP concentration of $0.05 \mathrm{mg} / \mathrm{L}$ in the water of shrimp and crabs polyculture pond was higher than that in either shrimp monoculture with $0.01 \mathrm{mg} / \mathrm{L}$ or crab monoculture with TP $0.03 \mathrm{mg} / \mathrm{L}$. In addition, the TP level of aquaculture water increased from $0.02 \mathrm{mg} / \mathrm{L}$ to $0.06 \mathrm{mg} / \mathrm{L}$ when aquaculture combinations from crabandfish polyculture to the crabs and various fish polycultures in the pond. Among all six ponds with different aquaculture systems, only in the polyculture pond with different types of fish was the TP concentration of $0.41 \mathrm{mg} / \mathrm{L}$ slightly higher than the standard limit of Class V of China Environmental Quality Standard for Surface Water $(0.4 \mathrm{mg} / \mathrm{L})$.

Thus, it can be deduced that the water bodies of the ponds with polyculture systems were in eutrophic status caused mainly by high levels of nitrogen and

Table 3. Correlation analysis of water quality parameters and nutritioningredient contents.

\begin{tabular}{|c|c|c|c|c|c|c|c|c|c|c|c|c|}
\hline & \multicolumn{4}{|c|}{ Physical parameters } & \multicolumn{7}{|c|}{ Chemical parameters } & \multirow{2}{*}{\begin{tabular}{|c}
$\begin{array}{c}\text { Biological } \\
\text { parameters }\end{array}$ \\
Chl.a
\end{tabular}} \\
\hline & $\mathrm{T}$ & SAL & $\mathrm{C}$ & OPR & $\mathrm{pH}$ & DO & $\mathrm{TN}$ & $\mathrm{NO}_{3}^{-}-\mathrm{N}$ & $\mathrm{NO}_{2}^{-}-\mathrm{N}$ & $\mathrm{NH}_{3}-\mathrm{N}$ & TP & \\
\hline $\mathrm{T}$ & & & & & & & & & & & & \\
\hline SAL & -0.146 & & & & & & & & & & & \\
\hline $\mathrm{C}$ & -0.022 & $0.990 * *$ & & & & & & & & & & \\
\hline OPR & -0.520 & 0.674 & 0.575 & & & & & & & & & \\
\hline $\mathrm{pH}$ & 0.673 & -0.516 & -0.438 & -0.691 & & & & & & & & \\
\hline DO & 0.687 & -0.582 & -0.514 & -0.666 & $0.954 * *$ & & & & & & & \\
\hline $\mathrm{TN}$ & -0.021 & 0.385 & 0.423 & 0.132 & -0.622 & -0.684 & & & & & & \\
\hline $\mathrm{NO}_{3}^{-}-\mathrm{N}$ & -0.598 & 0.200 & 0.152 & 0.367 & -0.758 & $-0.864 *$ & 0.730 & & & & & \\
\hline $\mathrm{NO}_{2}^{-}-\mathrm{N}$ & 0.247 & 0.642 & 0.720 & 0.049 & -0.254 & -0.421 & 0.781 & 0.381 & & & & \\
\hline $\mathrm{NH}_{3}-\mathrm{N}$ & -0.094 & 0.355 & 0.391 & 0.075 & -0.420 & -0.622 & $0.860^{*}$ & 0.786 & $0.826^{*}$ & & & \\
\hline $\mathrm{TP}$ & 0.584 & 0.475 & 0.582 & -0.102 & 0.060 & -0.093 & 0.627 & 0.123 & $0.919 * *$ & 0.680 & & \\
\hline Chl.a & 0.624 & 0.515 & 0.625 & -0.105 & 0.083 & -0.047 & 0.579 & 0.022 & $0.904 *$ & 0.595 & $0.991 * *$ & \\
\hline
\end{tabular}

* Correlation is significant, $\mathrm{P}<0.05$

** Correlation is extremely significant, $\mathrm{P}<0.01$ 
phosphorus. This deterioration of water quality would greatly threaten the yield and quality of fish in the aquaculture pond. Moreover, the high nitrogen and phosphorus levels in the water body are the main reasons for the outbreak of cyanobacteria and water blooms [21], which also resulted in high content of chlorophyll a in the aquaculture water.

\section{Correlation Analysis of Water Quality Parameters in Aquaculture Ponds}

The correlation between water quality parameters in each aquaculture pond was analyzed (Table 3). Significant positive correlations were found between the SAL and the electrical conductivity $(r=0.990, \mathrm{P}<0.01)$ and between the $\mathrm{DO}$ and $\mathrm{pH}$ value $(\mathrm{r}=0.954, \mathrm{P}<0.01)$. Conversely, negative correlations existed between DO and TN or TP, and between DO and different forms of nitrogen. Therefore, it could be deduced that the higher the concentration of nitrogen and phosphorus in aquaculture water, the lower the dissolved oxygen in the aquaculture water. In addition, a positive correlation was found between $\mathrm{TN}$ and $\mathrm{NO}_{3}{ }^{-} \mathrm{N}$ or between $\mathrm{TN}$ and $\mathrm{NO}_{2}{ }_{2}^{-} \mathrm{N}$, or between $\mathrm{TN}$ and $\mathrm{NH}_{3}$ in aquaculture water, with correlation coefficients of $0.730,0.781$, and 0.860 , respectively. However, no significant positive correlation was detected between $\mathrm{TN}$ and $\mathrm{TP}$ in aquaculture ponds, but there was a significant positive correlation between TP and chlorophyll a content in this study $(\mathrm{r}=0.991$, $\mathrm{P}<0.01)$. This positive correlation between chlorophyll a and TP was in accordance with previous studies [22-24].

\section{Conclusions}

As one of the most representative areas of China's aquaculture, Jiangsu Province owns a large number of aquaculture systems. To investigate and analyze water quality in different aquaculture systems in Jiang Province is of great significance to the adjustment of aquaculture structure and the development of ecological aquaculture in China. In the present study, comparative analysis revealed that the water quality in the monoculture mode of the shrimp or crab was the best among the six pond systems, while the water quality in polyculture of the different types of fish was the worst. The ammonia concentration in six aquaculture pond systems exceeded Chinese fishery aquaculture water standards $(0.20 \mathrm{mg} / \mathrm{L})$ in winter. The results demonstrated that the pond aquaculture in China is in an extensive management state and the corresponding control strategy is urgent. Considering the characteristics of regional aquaculture in Jiangsu province, it is highly recommended to promote the ecological and environmentally friendly aquaculture technology, such as integrated breeding, multi-nutrient aquaculture, compound artificial wetland, and pond aquaculture with water circulation. These measures could contribute to solving a series of unbalanced, uncoordinated and unsustainable problems that occurred during the process of pond aquaculture, so as to form an ecological aquaculture mode suitable for developing aquaculture industry and also having a larger water environment capacity.

\section{Acknowledgements}

The authors thank the programs of Three Reforms in Aquaculture Engineering of Jiangsu Province (grant No. Y2017-27). Thanks also go to Jiangsu Provincial Environmental Protection Scientific Research Project (grant No. 2016044) and Public Science and Technology Research Funds Projects of Ocean (grant No. 201505023).

\section{Conflict of Interest}

The authors declare no conflict of interest.

\section{References}

1. BUREAU OF FISHERIES, MINISTRY OF AGRICULTURE. China fishery statistical yearbook; China Agriculture Press: Beijing, 2016 [In Chinese].

2. MINISTRY OF CIVIL AFFAIRS. China Civil Affairs Statistical Yearbook-2014. China Statistics, 2014 (10), 2, 2015 [In Chinese].

3. XIANG J. Recent major advances of biotechnology and sustainable aquaculture in China. Curr. Biotech. 4 (3), 296,2015.

4. FREI M., BECKER K. Integrated rice-fish culture: Coupled production saves resources. Nat. Resour. Forum. 29 (2), 135, 2005

5. AHMED N., GARNETT S.T. Integrated rice-fish farming in Bangladesh: meeting the challenges of food security. Food Secur. 3 (1), 81, 2011.

6. ZHENG H., HUANG H., CHEN C., FU Z., XU H., TAN S., SHE W., LIAO X., TANG J. Traditional symbiotic farming technology in China promotes the sustainability of a flooded rice production system. Sustain. Sci. 12 (1), 155, 2017.

7. BOSMA R.H., NHAN D.K., UDO H.M.J., KAYMAK U. Factors affecting farmers' adoption of integrated ricefish farming systems in the Mekong delta, Vietnam. Rev. Aquacult. 4 (3), 178, 2012.

8. TSURUTA T., YAMAGUCHI M., ABE S.I., IGUCHI K.I. Effect of fish in rice-fish culture on the rice yield. Fish. Sci. 77 (1), 95, 2011.

9. ZHAO J.L., ZHANG L.C., GU Y.J. Research on coupling coordination between marine and regional economies in Jiangsu province. Mar. Sci. 40 (2), 102, 2016 [In Chinese].

10. FEDERATION W.E., AMERICAN PUBLIC HEALTH ASSOCIATION. Standard methods for the examination of water and wastewater; American Public Health Association (APHA): Washington, DC, USA, 2005.

11. MINISTRY OF ENVIRONMENTAL PROTECTION. Water quality-determination of ammonium-Nessler's reagent spectrophotometry (HJ 535-2009). Beijing, 2009 [In Chinese]. 
12. STATE ENVIRONMENTAL PROTECTION AGENCY OF CHINA. Water Quality-Determination of Nitratenitrogen-Ultraviolet Spectrophotometry (HJ/T 346-2007); China Environmental Science Press: Beijing, 2007 [In Chinese].

13. STATE ENVIRONMENTAL PROTECTION AGENCY OF CHINA. Environmental quality standard for surface water (GB 3838-2002); China Environmental Science Press: Beijing, 2002 [In Chinese].

14. EVANS D.H., CLAIBORNE J.B. The Physiology of Fishes, Third Edition; Crc Press: Boca Raton, Florida, USA, 2005.

15. STORMER J., JENSEN F.B., RANKIN J.C. Uptake of nitrite, nitrate, and bromide in rainbow trout, (Oncorhynchus mykiss): effects on ionic balance. Can. J. Fish. Aquat. Sci. 53 (9), 1943, 1996.

16. STATE ENVIRONMENTAL PROTECTION AGENCY OF CHINA. Water quality standard for fisheries (GB 11607-89); China Environmental Science Press: Beijing, 1989 [In Chinese].

17. SCHULER D.J., BOARDMAN G.D., KUHN D.D., FLICK G.J. Acute Toxicity of Ammonia and Nitrite to Pacific White Shrimp, Litopenaeus vannamei, at Low Salinities. J. World Aquacult. Soc. 41 (3), 438, 2010.

18. WANG F., LIU H.F., YANG L. Acute toxicity of nitrite nitrogen to goldfish juveniles. Fish. Sci. (Dalian). 29 (6), $369,2010$.
19. KEALLEY M. Enviro notes: Water quality outcomes and profit: Not mutually exclusive. Australian Canegrower. 7, 2012.

20. SORICHETTI R.J., MCLAUGHLIN J.T., CREED I.F., TRICK C.G. Suitability of a cytotoxicity assay for detection of potentially harmful compounds produced by freshwater bloom-forming algae. Harmful Algae. 31 (1), 177, 2014.

21. WAGNER T., SORANNO P.A., WEBSTER K.E., CHERUVELIL K.S. Landscape drivers of regional variation in the relationship between total phosphorus and chlorophyll in lakes. Freshwater Biol. 56 (9), 1811, 2011.

22. PAERL H.W., MOISANDER P.H., DYBLE J. Harmful freshwater algal blooms, with an emphasis on cyanobacteria. The scientific world J. 1 (1), 76, 2011.

23. TOMASSO J.R., CARMICHAEL G.J. Acute toxicity of ammonia, nitrite, and nitrate to the guadalupe bass, Micropterus treculi. B. Environ. Contam. Tox. 36 (6), 866, 1986.

24. CHEN Y.G., LIU W.L., HAN H.J., HU W.P. Relationships between chlorophyll-a content and TN and TP concentrations in water bodies of Taihu Lake, China. Chinese J. Ecol. 26 (12), 2062, 2007. 